Endocrinol. Japon. 1960, 7 (4), $311 \sim 316$

\title{
FEEDBACK MECHANISM BETWEEN THYROID HORMONES AND HYPOTHALAMUS*
}

\author{
SUMIO SAITO, SATOSHI TOMIE, KAHEI NISHI, CHIAKI ABE, \\ TAKANOBU YAMAMOTO AND KISHUO SHIBUSAWA
}

Departmınt of Surgery, School of Medicine, Gunma University, Maebashi

It is a fact of great interest that when ${ }^{131}$ I-thyroxine and ${ }^{131}$ I-triiodothyronine are exogenously given, they are highly concentrated in the anterior hypothalamus, median eminence, and hypophysis.

Schittenhelm and Eisler (1932) already found that the intravenous injection of $1.0 \mathrm{mg} / \mathrm{kg}$ of thyroxine $\left(\mathrm{T}_{4}\right)$ into dogs, cats and rabbits elevated iodine concentration in the tuber cinereum 10 times.

Since the introduction of ${ }^{131}{ }^{-}-\mathrm{T}_{4}$, studies in this field have made a remarkable advance, and Harper and Mattis (1950, 1951), Jensen and Clark (1951), and Courrier et al. (1951), using this method, nearly simultaneously confirmed the results of Schittenhelm and Eisler (1932). Although this phenomenon was observed very distinctly in dogs and rabbits, it did not seem to occur so remarkably in all the animals. ${ }^{131} \mathrm{I}-\mathrm{T}_{4}$ concentration was found in the descending order, in the neurohypophysis, the stalk, and the median eminence. Ford et al. (1955) obtained a similar result with ${ }^{131} \mathrm{I}_{-} \mathrm{T}_{3}$, and Courrier (1957) reported that $3,5^{\prime}, 3^{\prime}-\mathrm{L}-\mathrm{T}_{3}$ showed the highest affinity to these sites, followed by $3,3^{\prime}$-L-diiodothyronine and $\mathrm{T}_{4}$. Taurog et al. $(1956,1957)$ could not observe such accumulation of thyroid hormone in rats and guinea pigs. According to Ford et al. (1957), there is difference between ${ }^{131} I_{-} \mathrm{T}_{4}$ and ${ }^{131} \mathrm{I}-\mathrm{T}_{3}$ in the site of concentration, the latter being concentrated in the site where tissue oxygen consumption is higher. In experiments with rabbits, Ford and Gross (1958a) confirmed that $T_{3}$ was principally concentrated in Nucleus paraventricularis and the median eminence, and especially highly in the neurohypophysis. Ford and Gross (1958b) further observed the concentration of $\mathrm{T}_{3}$ in the neurosecretory system in guinea pigs. These reports suggest that $\mathrm{T}_{3}$ and $\mathrm{T}_{4}$ are related, at a higher level than the hypophysis, to the hypothalamohypophysio-thyroidal system. Previously the authors extracted thyrotrophin releasing factor (TRF) from the anterior hypothalamus, including neurosecretory nuclei, which controled the hypophysio-thyroidal system, and was presumably related to exogenous $\mathrm{T}_{3}$ and $\mathrm{T}_{4}$. The relationship between the secretion of TSH and the concentration of $\mathrm{T}_{3}$ or $\mathrm{T}_{4}$ in the hypothalamus was therefore studied by the administration of non-labelled $\mathrm{T}_{3}$ and $-\mathrm{T}_{4}$.

\footnotetext{
Received for publication July 20, 1960.

* This work was supported in part by Grant in Aid for Scientific Research-Co-operate Research and for Developmental Scientific Research from the Ministry of Education.
} 


\section{MATERIALS AND METHODS}

\section{Materials}

Adult male dogs, weighing $10 \sim 15 \mathrm{~kg}$ were used. Female animals were not used because of the possible influence of sexual cycle. Through the course of experiments, special care was taken to keep the room temperature, light and nutrition as constant as possible.

II. Methods

(1) Determination of $T_{3}$ and $T_{4}$ in the hypothalamus and hypophysis

Two hrs. after intramuscular injection of $T_{3}$ and $T_{4}$, animals were sacrificed by electroshock, and the hypophysis and hypothalamus were excised. The hypothalamus was fixed with acetone, frozen with dry ice and divided into anterior, medial and posterior parts to be weighed separately. The anterior part included the optic chiasm and the frontal rim of the median eminence, the posterior part covered the area from the dorsal rim of the median eminence to the mamillary body, and the medial part was the area between the above two. The hypophysis was not divided into the anterior and posterior lobe, to keep the error of the measurement as small as possible. The 3 parts of the hypothalamus and the hypophysis were homogenized, subjected to enzymic hydrolysis by the Suzuki's method (1956), adjusted to $\mathrm{pH} 5$, and extracted 3 times with 10,5 , and 5 volumes of $\mathrm{n}$-butanol, respectively. These extract solutions were desiccated and solidified at temperature below $45^{\circ} \mathrm{C}$ under a decreased pressure, and then dissolved in $0.4 \mathrm{ml}$ of $30 \%$ isopropanol for extraction. After 10 mins. centrifugation, $0.1 \mathrm{ml}$ of the supernatant was placed on Toyo Roshi filter paper No. 50 for quantitative analysis. Blood concentrations of $\mathrm{T}_{3}$ and $\mathrm{T}_{4}$ were determined by paper partition chromatography according to the Tomie's method (1959). These were expressed in term of iodine contained in the spots of $T_{3}$ and $T_{4}$.

(2) Determination of blood TRF was performed by the Yamamoto's method (1959). Unit of TRF was showed as the amount of $\mathrm{TSH}$, which was determined according to Crooke and Mathews (1953) and expressed in term of J.S.U. (Shibusawa et al., 1959).

(3) Determination of PBI was performed according to the method of Barker et al. (1950).

(4) Determination of blood $\mathrm{T}_{3}$ and $\mathrm{T}_{4}$ was performed, as afore mentioned, by the method of Tomie (1959).

(5) $\mathrm{T}_{3}$ and $\mathrm{T}_{4}$ are commercial products of Sigma Co. They were dissolved in distilled water adjusted to $\mathrm{pH} 8.5$, and $5 \sim 7 \mu \mathrm{g} / \mathrm{kg}$ weight was intramuscularly injected at one time.

\section{RESULTS}

(1) Concentrations of $T_{3}$ and $T_{4}$ in tho hypothalamus and hypophysis after the ientramuscular administration of $T_{3}$

As shown in Table 1 , the content of $\mathrm{T}_{4}$ per each $1 \mathrm{mg}$ of the posterior hypothalamic tissue was perfectly same with the control. $\mathrm{T}_{3}$ concentration also scarcely differed from the control, though in some cases it was impossible to determine the concentration. No significant difference from the control was observed in the concentrations of $T_{4}$ and $T_{3}$ in the medial hypothalamus, though in some cases the determination of $\mathrm{T}_{3}$ concentration was impossible. In the anterior hypothalamus, $\mathrm{T}_{4}$ concentration increased after the injection of $\mathrm{T}_{3}$, but there was no significant difference in $T_{3}$ from the control. In the hypophysis, scarcely any difference from the control was observed in $\mathrm{T}_{4}$ concentration, while $\mathrm{T}_{3}$ was significantly increased. Levels of PBI, $T_{3}, T_{4}$, and TRF in the peripheral venous blood showed, as exhibited in Table 2, evident decrease at 2 hrs. after the injection. It is of significant that the level of TRF showed a decrease following the intramuscular injection of $T_{3}$. 
Table 1. Concentration of $T_{3}$ and $T_{4}$ in the hypothalamus and hypophysis of dogs after the intramuscular injection of $\mathrm{T}_{3}$

\begin{tabular}{|c|c|c|c|c|c|c|}
\hline \multirow{2}{*}{\multicolumn{2}{|c|}{$\begin{array}{l}\text { No. of } \\
\text { dogs }\end{array}$}} & \multirow{2}{*}{$\begin{array}{l}\text { Wet tissue } \\
\text { weight } \\
\text { (mg)* }\end{array}$} & \multicolumn{2}{|r|}{$\mathrm{T}_{4}$ concentration } & \multicolumn{2}{|c|}{$T_{3}$ concentration } \\
\hline & & & $(\mu g)^{*}$ & $(\mu \mathrm{g} / \mathrm{mg}$ tissue weight)* & $(\mu \mathrm{g})^{*}$ & $(\mu \mathrm{g} / \mathrm{mg}$ tissue weight)* \\
\hline \multicolumn{7}{|c|}{ Posterior hypothalamus } \\
\hline$T_{3}$ injected & 8 & $883 \pm 13$ & $0.044 \pm 0.013$ & $0.50 \pm 0.14 \times 10^{-4}$ & $0.005 \pm 0.003$ & $0.05 \pm 0.03 \times 10^{-4}$ \\
\hline Control & 5 & $785 \pm 21$ & $0.039 \pm 0.008$ & $0.51 \pm 0.12 \times 10^{-4}$ & $0.003 \pm 0.002$ & $0.04 \pm 0.02 \times 10^{-4}$ \\
\hline \multicolumn{7}{|c|}{ Medial hypothalamus } \\
\hline$T_{3}$ injected & 7 & $853 \pm 62$ & $0.062 \pm 0.009$ & $0.72 \pm 0.13 \times 10^{-4}$ & $0.005 \pm 0.004$ & $0.05 \pm 0.03 \times 10^{-4}$ \\
\hline Control & 5 & $832 \pm 38$ & $0.059 \pm 0.003$ & $0.71 \pm 0.24 \times 10^{-4}$ & $0.004 \pm 0.002$ & $0.05 \pm 0.02 \times 10^{-4}$ \\
\hline \multicolumn{7}{|c|}{ Anterior hypothalamus } \\
\hline$T_{3}$ injected & 9 & $635 \pm 67$ & $0.116 \pm 0.029$ & $1.62^{1} \pm 0.43 \times 10^{-4}$ & $0.065 \pm 0.005$ & $1.02 \pm 0.09 \times 10^{-4}$ \\
\hline Control & 6 & $582 \pm 84$ & $0.063 \pm 0.002$ & $1.08^{1} \pm 0.35 \times 10^{-4}$ & $0.062 \pm 0.004$ & $1.06 \pm 0.07 \times 10^{-4}$ \\
\hline \multicolumn{7}{|l|}{ Hypophysis } \\
\hline$T_{3}$ injected & 6 & $137 \pm 9$ & $0.43 \pm 0.010$ & $3.15 \pm 0.74 \times 10^{-4}$ & $0.027 \pm 0.005$ & $1.96^{2} \pm 0.35 \times 10^{-4}$ \\
\hline Control & 5 & $132 \pm 11$ & $0.044 \pm 0.009$ & $3.34 \pm 0.68 \times 10^{-4}$ & $0.016 \pm 0.006$ & $1.21^{2} \pm 0.43 \times 10^{-4}$ \\
\hline
\end{tabular}

Table 2. Concentration of $\mathrm{PBI}, \mathrm{T}_{3}, \mathrm{~T}_{4}$, and TRF in the peripheral venous blood of dogs after the injection of $T_{3}$

\begin{tabular}{lccccc}
\hline \hline & $\begin{array}{c}\text { No. of } \\
\text { dogs }\end{array}$ & $\begin{array}{c}\text { PBI } \\
(\mu \mathrm{g} \%)^{*}\end{array}$ & $\begin{array}{c}\mathrm{T}_{4} \\
(\mu \mathrm{g} \%)^{*}\end{array}$ & $\begin{array}{c}\mathrm{T}_{3} \\
(\mu \mathrm{g} \%)^{*}\end{array}$ & $\begin{array}{c}\text { TRF } \dagger \\
(\mathrm{TSH}, \text { J.S.U.\%)* }\end{array}$ \\
\hline Before injection & 6 & $2.5 \pm 0.3$ & $2.0 \pm 0.2$ & $0.3 \pm 0.1$ & $0.25 \pm 0.01$ \\
2 hrs. after injection & 8 & $1.8 \pm 0.4$ & $1.0 \pm 0.1$ & $0.2 \pm 0.1$ & $0.13 \pm 0.005$ \\
\hline
\end{tabular}

* Mean \pm Standard error

$\uparrow$ TRF value was showed as equivalent potency of TSH (J.S.U.). See text.

It was thus demonstrated that the administration of $T_{3}$ into the systemic circulation increased the concentration of $\mathrm{T}_{4}$ in the anterior hypothalamus, and that of $T_{3}$ in the hypophysis, while no changes in the concentrations of $T_{3}$ or $T_{4}$ were seen in the medial and posterior hypothalamus.

(2) Concentrations of $T_{3}$ and $T_{4}$ in the hypothalamus and hypophysis after the intramuscular administration of $T_{4}$

In the posterior and medial hypothalamus, $T_{3}$ and $T_{4}$ concentrations did not show any significant difference from the control (Table 3). In the anterior hypothalamus, however, the level of $\mathrm{T}_{4}$ showed any increase over the control, and that of $T_{3}$ also a marked increase. In the hypophysis, the level of $T_{4}$ increased over the control.

PBI, $\mathrm{T}_{3}, \mathrm{~T}_{4}$, and TRF in the peripheral venous blood all showed a decrease at $2 \mathrm{hrs}$. after the injection of $\mathrm{T}_{4}$ (Table 4). It was thus shown that exogenously given $T_{4}$ increased the concentrations of $T_{3}$ and $T_{4}$ in the anterior hypothalamus, whereas the medial and posterior hypothalamus did not respond to this administration. 
Table 3. Concentrations of $T_{3}$ and $T_{4}$ in the hypothalamus and hypophysis of dogs after the intramuscular injection of $\mathrm{T}_{4}$

\begin{tabular}{|c|c|c|c|c|c|c|}
\hline \multirow{2}{*}{\multicolumn{2}{|c|}{$\begin{array}{c}\text { No. of } \\
\text { dogs }\end{array}$}} & \multirow{2}{*}{$\begin{array}{c}\text { Wet tissue } \\
\text { weight } \\
\text { (mg)* }\end{array}$} & \multicolumn{2}{|r|}{$T_{4}$ concentration } & \multicolumn{2}{|c|}{$\mathrm{T}_{3}$ concentration } \\
\hline & & & $(\mu g)^{*}$ & $(\mu \mathrm{g} / \mathrm{mg}$ tissue weight)* & $(\mu \mathrm{g})^{*}$ & $(\mu \mathrm{g} / \mathrm{mg} \text { tissue weight })^{*}$ \\
\hline \multicolumn{7}{|c|}{ Posterior hypothalamus } \\
\hline$T_{4}$ injected & 8 & $795 \pm 38$ & $0.042 \pm 0.005$ & $0.53 \pm 0.04 \times 10^{-4}$ & $0.003 \pm 0.002$ & $20.04 \pm 0.01 \times 10^{-4}$ \\
\hline Control & 5 & $786 \pm 20$ & $0.039 \pm 0.007$ & $0.50 \pm 0.01 \times 10^{-4}$ & $0.004 \pm 0.002$ & $20.05 \pm 0.02 \times 10^{-4}$ \\
\hline \multicolumn{7}{|c|}{ Medial hypothalamus } \\
\hline$T_{4}$ injected & 7 & $821 \pm 19$ & $0.058 \pm 0.002$ & $0.70 \pm 0.02 \times 10^{-4}$ & $0.005 \pm 0.03$ & $0.05 \pm 0.02 \times 10^{-4}$ \\
\hline Control & 5 & $823 \pm 12$ & $0.056 \pm 0.003$ & $0.68 \pm 0.03 \times 10^{-4}$ & $0.005 \pm 0.03$ & $0.05 \pm 0.02 \times 10^{-4}$ \\
\hline \multicolumn{7}{|c|}{ Anterior hypothalamus } \\
\hline$T_{4}$ injected & 8 & $629 \pm 53$ & $0.125 \pm 0.026$ & $1.98^{1} \pm 0.43 \times 10^{-4}$ & $0.193 \pm 0.072$ & $23.05^{2} \pm 0.11 \times 10^{-4}$ \\
\hline Control & 5 & $570 \pm 24$ & $0.063 \pm 0.005$ & $1.13^{1} \pm 0.09 \times 10^{-4}$ & $0.061 \pm 0.021$ & $1.06^{2} \pm 0.03 \times 10^{-4}$ \\
\hline \multicolumn{7}{|l|}{ Hypophysis } \\
\hline$T_{4}$ injected & 9 & $138 \pm 10$ & $0.135 \pm 0.02$ & $9.75^{3} \pm 0.14 \times 10^{-4}$ & $0.064 \pm 0.008$ & $3 \quad 4.64^{4} \pm 0.55 \times 10^{-4}$ \\
\hline Control & 5 & $135 \pm 6$ & $0.044 \pm 0.001$ & $3.25^{3} \pm 0.09 \times 10^{-4}$ & $0.016 \pm 0.005$ & $5 \quad 1.18^{4} \pm 0.35 \times 10^{-4}$ \\
\hline
\end{tabular}

* Mean \pm Standard error

The differences between the pairs values of individual group in Student's t-test; $1: P<0.05$, $2: P<0.02,3: P<0.03$ and $4: P<0.02$.

Table 4. Concentration of $\mathrm{PBI}_{2} \mathrm{~T}_{3}, \mathrm{~T}_{4}$ and $\mathrm{TRF}$ in the peripheral venous blood of dogs after the injection of $T_{4}$

\begin{tabular}{|c|c|c|c|c|c|}
\hline & $\begin{array}{l}\text { No. of } \\
\text { dogs }\end{array}$ & $\begin{array}{c}\mathrm{PBI} \\
(\mu \mathrm{g} \%)^{*}\end{array}$ & $\begin{array}{c}T_{4} \\
(\mu \mathrm{g} \%)^{*}\end{array}$ & $\begin{array}{c}\mathrm{T}_{3} \\
(\mu \mathrm{g} \%)^{*}\end{array}$ & $\begin{array}{c}\text { TRF } \dagger \\
(T S H, \text { J.S.U.\%)* }\end{array}$ \\
\hline Before injection & 5 & $2.5 \pm 0.3$ & $2.0 \pm 0.2$ & $0.3 \pm 0.1$ & $0.25 \pm 0.01$ \\
\hline 2 hrs. after iniection & 5 & $1.5 \pm 0.2$ & $1.1 \pm 0.1$ & $0.2 \pm 0.1$ & $0.14 \pm 0.005$ \\
\hline
\end{tabular}

* Mean \pm Standard error

$\dagger$ TRF value like as shown in Table 2.

\section{DISCUSSION}

Previously the authors succeeded in extracting, from the anterior hypothalamus, TRF, a neurohumor which controls the release of TSH (Shibusawa et al., 1956a, 1959a).

It was later confirmed that when $\mathrm{T}_{4}$ or $\mathrm{T}_{3}$ was localiy administered into the anterior hypothalamus, the release of TRF was inhibited (unpublished data). $\mathrm{T}_{4}$ and $\mathrm{T}_{3}$ were subsequently considered to take part in feed back mechanism together with TRF, controlling in this way the secretion of pituitary TSH. In the present experiments the authors attempted to ascertain further the feed back relation between thyroid hormones and TRF at the level of the anterior hypothalamus.

Many workers have already recognized the accumulation of ${ }^{131} I$ in the neurosecretory system such as the median eminence, paraventricular nucleus, and neurohypophysis when ${ }^{131} \mathrm{I}-\mathrm{L}-\mathrm{T}_{4}$ and ${ }^{131} \mathrm{I}-\mathrm{L}-\mathrm{T}_{3}$ were administered. For example, Ford and Gross (1958a) reported that when ${ }^{13 I} I-T_{4}$ and $-T_{3}$ were injected into 
rabbits, the highest accumulation was seen in the neurohypophysis, and next in the adenohypophysis, while the concentrations in the hypothalamus were equal to those in the pons and medulla. In similar experiments with guinea pigs they also observed accumulation of ${ }^{131} \mathrm{I}$ in the descending order of the adenohypophysis, tuber cinereum, and neurohypophysis.

In the authors' results in dogs, $\mathrm{T}_{4}$ concentration in the anterior hypothalamus showed an evident increase at $2 \mathrm{hrs}$. after the injection of $\mathrm{T}_{3}$. In the hypophysis, $\mathrm{T}_{4}$ concentration displayed no change, while $\mathrm{T}_{3}$ showed a significant increase. The injection of $T_{3}$ did not produce any change in $T_{3}$ and $T_{4}$ concentration in the medial and posterior hypothalamus. On the other hand, the injection of $\mathrm{T}_{4}$ increased $\mathrm{T}_{4}$ concentration in the anterior hypothalamus nearly twice and $\mathrm{T}_{3}$ nearly to 3 times. Since these results were obtained with dogs, difference from those by Ford et al. (1957), which were obtained with guinea pigs and rabbits, might be expected. Nevertheless the increase of $T_{3}$ and $T_{4}$ in the anterior hypothalamus seemed to correspond with the earlier results that TRF was produced in the anterior hypothalamus, and to attain the posterior lobe of the hypophysis through the neurosecretory tract (Shibusawa et al., 1959b, c). It is therefore highly probable that exogenously given $\mathrm{T}_{3}$ or $\mathrm{T}_{4}$ might be linked with TRF in the feedback type in the neurosecretory system of the hypothalamus. When $T_{3}$ and $T_{4}$ concentrations in the anterior hypothalamus were increased their concentrations in peripheral venous blood would fall as the consequence.

Von Euler and Holmgren (1956) observed that $\mathrm{L}_{-} \mathrm{T}_{4}$, injected into the adenohypophysis of the rabbit, inhibited the liberation of ${ }^{131}$ I from the thyroid, while the same hormone in the same dose was ineffective when injected into the hypothalamus and the median eminence. On this ground they concluded that $\mathrm{T}_{4}$ has a feedback relation with TSH solely at the level of the hypophysis. Florsheim (1958), who carried out experiments with rats, considered the thyroid-pituitary feedback system controling the secretion of TSH to be independent on the hypothalamus. However, Yamada and Greer (1959) reported the inhibition of thyroidal ${ }^{131} \mathrm{I}$ uptake by $\mathrm{T}_{4}$ injected into the anterior hypothalamus and the anterior lobe of the hypophysis, but the injection into the medial hypothalamus or the anterior lobe of the hypophysis showed no such effect. These reports suggest the participation of the anterior hypothalamus in the pituitary-thyroid feedback system. The authors found that when $\mathrm{T}_{3}$ or $\mathrm{T}_{4}$ was injected into the anterior hypothalamus or the anterior lobe of the hypophysis, blood concentration of TRF decreased, probably due to the effect of thyroid hormones at the hypothalamic level. In the present series of experiments of exogenous administration of $\mathrm{T}_{3}$ and $\mathrm{T}_{4}$, the rise in the concentrations of $\mathrm{T}_{3}$ and $\mathrm{T}_{4}$ in the systemic circulation resulted in an inhibition of the release of TRF from the anterior hypothalamus consequently leading to the decrease in the release of TSH from the hypophysis and of $\mathrm{T}_{3}$ and $\mathrm{T}_{4}$ from the thyroid. TSH secretion thus appears to be not only controled by the thyroid-pituitary feedback relationship at the level of the hypophysis, but also supplemented by thyroid-TRF feedback mechanism at the level of the anterior hypothalamus. 


\section{SUMMARY}

(1) After the intramuscular injection of $T_{3}, T_{4}$ was increased in the anterior hypothalamus, and $\mathrm{T}_{3}$ in the hypophysis.

(2) Two hrs. after the intramuscular injection of $\mathrm{T}_{4}, 2$ fold increase of $\mathrm{T}_{4}$ and 3 fold of $\mathrm{T}_{3}$ were seen in the anterior hypothalamus, while in the hypophysis, $\mathrm{T}_{4}$ increased 3 times, and $T_{3} 4$ times. No change was observed in the medial and the posterior hypothalamus.

(3) $\mathrm{T}_{3}$ and $\mathrm{T}_{4}$ are considered to constitute feedback type mechanism with TRF and TSH, respectively.

\section{REFERENCES}

Barker, S. B. and M. J. Humphray (1950). J. Clin. Endocrinol. 10, 1136.

Courrier, R. (1957). Ciba Foundation Colloquia on Endocrinol. 10, 21.

Courrier, R., A. Horeau, M. Marois and F. Morel, (1951). Compt. rend. soc. biol. 143, 935.

Crooke, A. C. and J. D. Mathews (1953). Ciba Foundation Colloquia on Endocrinol. 5, 25.

Florsheim, W. H. (1958). Endocrinology 62, 783.

Ford. D. H., M. Posner and J. Gross (1955). Anat. Record 121, 294.

Ford, D. H., K. R. Corey and J. Gross (1957). Endocrinology 61, 426.

Ford, D. H. and J. Gross (1958a). Endocrnology 62, 415.

Ford, D. H. and J. Gross (1958b). Endocrinology 63, 549.

Harper, E. O. and P. A. Mattis (1950). Federation Proc. 9, 282.

Harper, E. O. and P. A. Mattis (1951). Federation Proc. 10, 306.

Jensen, J. M. and D. E. Clark (1951). J. Lab. Clin. Med. 38, 663.

Shibusawa, K., S. Saito, K. Nishi, T. Yamamoto, C. Abe, and K. Tomizawa (1956a). Endocrinol. Japon. 3, 116.

Shibusawa, K., K. Nishi and C. Abe (1959a). Endocrinol. Japon. 6, 29.

Shibusawa, K., T. Yamamoto, K. Nishi, C. Abe and S. Tomie (1959b). Endocrinol. Japon. 6, 137.

Shibusawa, K., T. Yamamoto, K. Nishi, C. Abe, S. Tomie and K. Shirota (1959c). Endocrinol. Japon. 6, 149.

Schittenhelm, A. and B. Eisler (1932). Klin. Wochenschr. 11, 9.

Suzuki, M. (1956). Endocrinol. Japon. 3, 291.

Taurog, A., G. W. Harris, W. Tong, I. L. Chaikoff (1956). Endocrinology 59, 34.

Taurog, A., W. Tong, and I. L. Chaikoff (1957). Ciba Foundation Colloquia on Endocrinol. 10, 59.

Tomie, S. (1959). Folia Endocrinol. Japon. 35, 868. (In Japanese)

Von Euler, C. and B. Holmgren (1956). J. Physiol. 131, 125.

Yamada, T. and N. A. Greer (1959). Endocrinology 64, 559.

Yamamoto, T. (1959). Folia Endocrinol. Japon. 35, 638. (In Japanese) 